\title{
Studies on riparian communities in eastern Morocco: coastal dayas at the mouth of the Moulouya River
}

\author{
Naoual Zitouni ${ }^{1, *}$, and Guy Chavanon ${ }^{1}$ \\ ${ }^{1}$ « Laboratoire d'Amélioration de la Production Agricole, Biotechnologie et Environnement », Faculty of Sciences, Mohammed Ist \\ University, Oujda, Morocco
}

\begin{abstract}
This paper aims to study the riparian community of coastal dayas at the mouth of the Moulouya River in the northeast of Morocco. We carried out a monthly sampling of riparian fauna on two dayas (EMDI \& EMDII) on the Mediterranean coast. Banks of these dayas are an ecotone where terrestrial, riparian, and aquatic species mix. Riparian species dominate the population in richness and abundance: most species are either sporadic (EMDI) or accidental (EMDII). The dominant species are halophilous. Interesting species have been collected from these dayas: Gonocephalum yelamosi, new species for Morocco, Blaps nitens, Dyschirius tensicollis, and Dyschirius africanus, which dayas is a new distribution in the region. Species with the same ecological niches that can compete with each other seem to share the occupation of this environment. The same phenomenon seems to occur for species of the genus Pogonus and Pogonistes, which have populations that reach their maximum expansion at different periods.
\end{abstract}

\section{Introduction}

Riparian communities are made up of species that colonize the wet banks of aquatic environments (ocean, river, torrent, the body of water, dayas, etc.) whatever its size and as long as it is not dried up.

They are colonized by a diversified population, a mixture of terrestrial, riparian, and aquatic origins. They are highly migratory species that can leave the environment as soon as conditions become unfavorable and recolonize others just as quickly. These communities depend on their environment and have rigorous ecological and ethological requirements, making them very originals. They are a diversified mixture of species of terrestrial, riparian, and aquatic origins. The temporary nature and instability of the colonize environments have led them to adapt both ethologically, ecomorphological, and ecophysiologically. This gives them certain originality.

The limited Spatio-temporal position of these habitats allows a comprehensive study of the functioning of their communities. The results thus obtained can easily be extrapolated to more significant situations and applied to more general ecological theories [1].

This particular environment will be the subject of this study. It aims to contribute to the knowledge of riparian environments in general and coastal environments in particular.

\section{Materials and methods}

\subsection{Study area}

The two dayas studied are temporary coastal water bodies fed mainly by rainwater (EMDI and EMDII) and groundwater. They dry up in summer (EMDI). They are located near the mouth of the Moulouya (Fig. 1).

Embouchure's Daya I (EMDI) is $200 \mathrm{~m}$ long and $70 \mathrm{~m}$ wide and is relatively deep. Its water is salty with a neutral $\mathrm{pH}$, and the substrate is sandy to sandy-silt with a neutral $\mathrm{pH}$. It appears in winter (January) and dries up in summer (July). The riparian vegetation consists mainly of Salicornia $s p$. The banks are narrow and sloping at the beginning and become more comprehensive as it dries out.

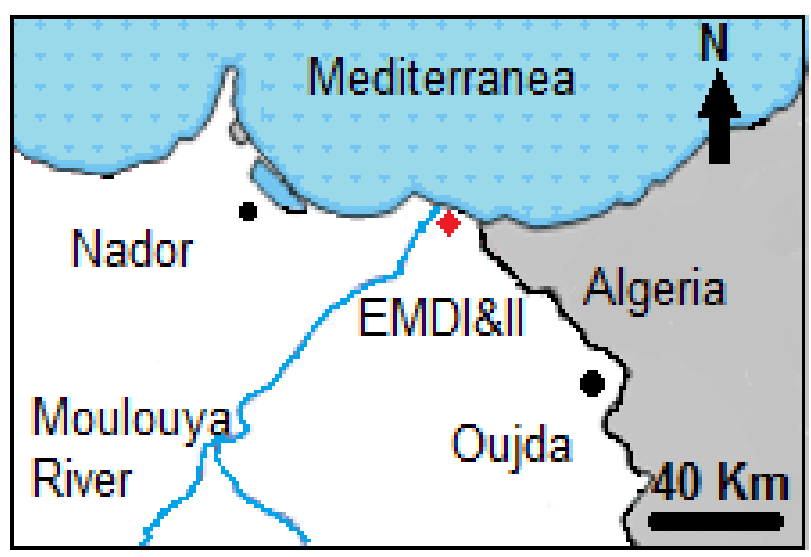

Fig. 1. The geographical location of the study area

\footnotetext{
* Corresponding author: zitouninaoual $@$ yahoo.fr
} 
Embouchure's Daya II (EMDII) is a very shallow daya, which reaches a maximum length of $90 \mathrm{~m}$ and a width of $35 \mathrm{~m}$ (January) and dries out in late spring (May). It has salty water with a neutral $\mathrm{pH}$ and a silty to a sandysilty substrate with a neutral $\mathrm{pH}$. Its banks are affluent in organic matter and plant debris.

\subsection{Sampling}

Surveys were carried out monthly for two consecutive years (two sampling campaigns).

Harvesting was carried out by direct sight hunting during a one-hour active search [2]. All shelters were surveyed, and all fauna found on the banks were collected.

The identifications of Caraboidea were carried out using Antoine's keys [3-7], the other groups were submitted to several specialists.

\section{Results and discussion}

Thirty-four species were collected on the banks of the coastal dayas of the Embouchure, 27 species on EMDI (Table 1), and 18 species on EMDII (Table 2).

Table 1. Species recorded in EMDI

\begin{tabular}{|c|c|}
\hline & Abundance \\
\hline \multicolumn{2}{|l|}{ CARABOIDEA } \\
\hline Tachys scutellaris dimidiatus & 198 \\
\hline Pogonus chalceus & 171 \\
\hline Pogonus gilvipes & 143 \\
\hline Pogonistes gracilis & 68 \\
\hline Syrdenus grayi & 49 \\
\hline Emphanes normanus & 34 \\
\hline Notaphus ephippium & 24 \\
\hline Trichis maculata & 12 \\
\hline Cicindela maura & 10 \\
\hline Cephalota litorea goudoti & 7 \\
\hline Dichirotrichus obsoletus & 7 \\
\hline Pogonus luridipennis flavipennis & 6 \\
\hline Dyschirus dalila & 4 \\
\hline Lophyridia lunulata & 3 \\
\hline Dyschirus clypeatus & 2 \\
\hline Daptus vittatus & 2 \\
\hline Microlestes luctuosus & 1 \\
\hline Emphanes lais & 1 \\
\hline \multicolumn{2}{|l|}{ TENEBRIONIDAE } \\
\hline Blaps nitens & 1 \\
\hline \multicolumn{2}{|l|}{ STAPHYLINIDAE } \\
\hline Bledius bicornis & 11 \\
\hline Bledius (Bledius) unicornis & 7 \\
\hline Bledius (Euceratobledius) furcatus & 4 \\
\hline Bledius (Bledius) angustus & 1 \\
\hline Aloconota gregaria & 1 \\
\hline \multicolumn{2}{|l|}{ DYTISCIDAE } \\
\hline Agabus didymus & 2 \\
\hline Nebrioporus ceresyi & 1 \\
\hline \multicolumn{2}{|l|}{ HYDROPHILIDAE } \\
\hline Helochares lividus & 4 \\
\hline
\end{tabular}

A new species (Gonocephalum yelamosi) for Morocco has been collected from these dayas. In Morocco, they also represent a new station for Blaps nitens and a new station, in the region, for Dyschirius tensicollis and Dyschirius africanus.

Table 2. Species recorded in EMDII

\begin{tabular}{|c|c|}
\hline & Abundance \\
\hline \multicolumn{2}{|l|}{ CARABOIDEA } \\
\hline Dichirotrichus obsoletus & 22 \\
\hline Pogonus gilvipes & 12 \\
\hline Syrdenus grayi & 10 \\
\hline Dyschirus numidicus & 10 \\
\hline Tachys scutellaris dimidiatus & 9 \\
\hline Lophyridia lunulata & 4 \\
\hline Trichis maculata & 2 \\
\hline Cicindela maura & 2 \\
\hline Dyschirus clypeatus & 1 \\
\hline Dyschirus africanus & 1 \\
\hline Dyschirus tensicollis & 1 \\
\hline \multicolumn{2}{|l|}{ STAPHILINIDAE } \\
\hline Bledius (hesperophillus) debilis & 41 \\
\hline Bledius (Euceratobledius) furcatus & 2 \\
\hline Platysthetus nitens & 1 \\
\hline \multicolumn{2}{|l|}{ TENEBRIONIDAE } \\
\hline Gonocephalum yelamosi & 1 \\
\hline Pachychila haroldi & 1 \\
\hline Blaps nitens & 1 \\
\hline \multicolumn{2}{|l|}{ DYTISCIDAE } \\
\hline Nebrioporus ceresyi & 2 \\
\hline
\end{tabular}

The Caraboidea, with Trechidae and Scaritidae families, represent the main component of this type of environment, as in the case of the Spanish salt lagoons [8, 9].

Riparian species dominate the community in terms of both richness and abundance. They have an abundance of $99 \%$ (EMDI) to $93 \%$ (EMDII) of riparian species with 22 (78\%) and 14 (75\%) species, respectively. The remainder is distributed between species of terrestrial or aquatic origin.

The majority of species are either sporadic (EMDI, frequency $<10 \%$ ) or accidental (EMDII, $25 \%>$ frequency $>10 \%$ ) according to Facet's classification [10]. Very few of them are constant, with a frequency $>50 \%$, in the environment (table 3 ). These are generally halophilic species. On the other hand, diversity (according to the $\mathrm{H}$ index of Shannon and Wever [10]) reaches more than 3 bits, and the equitability varies between $67.2 \%$ (EMDI) and 80.5\% (EMDII).

Table 3. Constant species in EMDI et EMDII

\begin{tabular}{|l|c|c|}
\hline & EMDI & EMDII \\
\hline T. scutellaris dimidiatus & + &. \\
\hline P. chalceus & + &. \\
\hline P. gracilis & + &. \\
\hline P. gilvipes & + &. \\
\hline S. grayi & + &. \\
\hline D. obsoletus &. & + \\
\hline
\end{tabular}


Furthermore, the stability coefficient (according to Gautier [11]) is 1.65 and 1.35 in EMDI and EMDII stations, which are relatively stable communities. This indicates that the same species contingent dominates these stations and is found in successive samplings.

Despite their low abundance, tiger beetles appear successively in the banks of both dayas (Fig. 2 and 3).

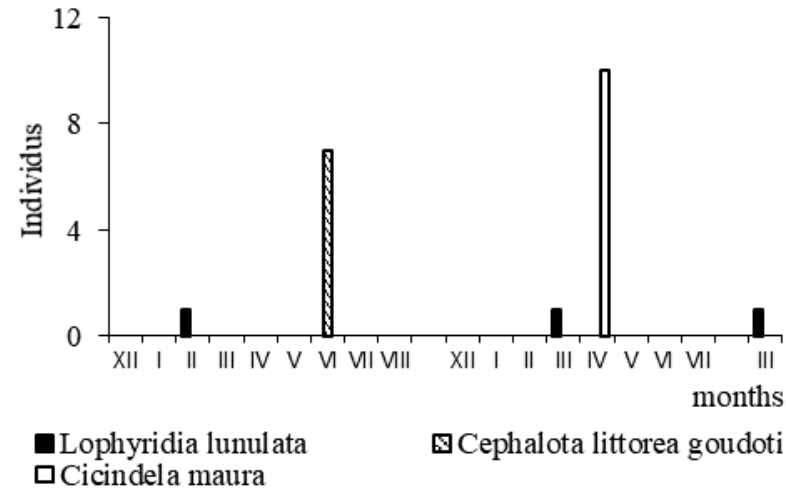

Fig. 2. Presence of Tiger beetles on the banks of daya EMDI depending on the month

Thus, L. lunulata is present during February and March, C. maura during April, and C. littorea goudoti during July. However, this succession was not noted by Chavanon [12], who observed the coexistence of tiger beetles on the banks of Moulouya River in perennial stations very close to ours.

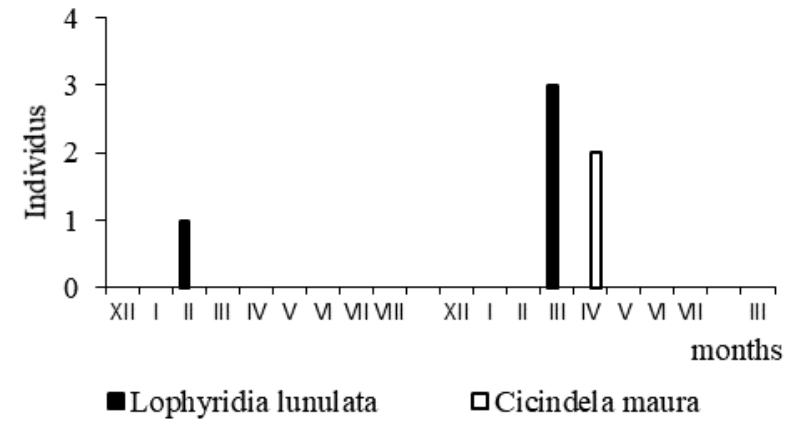

Fig. 3. Presence of Tiger beetles on the banks of daya EMDII depending on the month

A similar phenomenon occurs for species of genus Pogonus and Pogonistes. Indeed, it can be seen that despite an overlap in their period of presence on the banks of the EMDI daya, the populations reach their maximum expansion at different periods (Fig. 4).

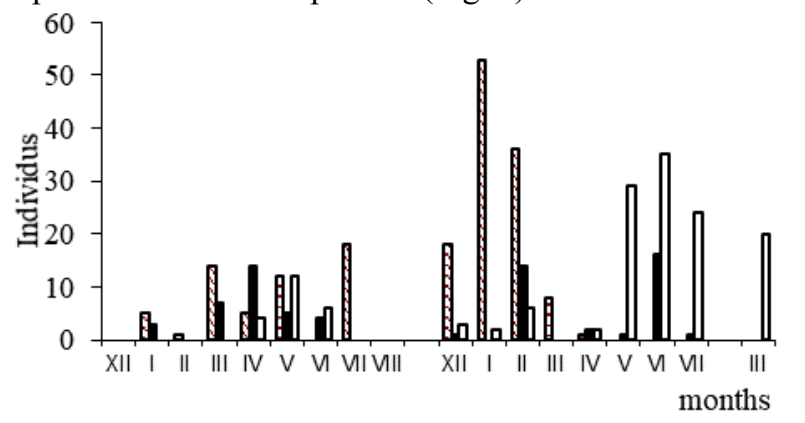

QP. chalceus $\square$. gracilis $\square$. gilvipes

Fig. 4. Presence of some species on the banks of daya EMDI depending on the month
In the campaign I, $P$. chalceus dominates during July, while $P$. gilvipes peaks in May and $P$. gracilis during April.

In campaign II, a clear division of the proliferation period between $P$. chalceus dominates from December to March, and P. gilvipes, which proliferates from May onwards. $P$. gracilis is dominant in the middle of the cycle in both campaigns.

\section{Conclusion}

Banks of coastal dayas at the mouth of Moulouya are colonized by a diversified community, a mixture of species of terrestrial, aquatic and riparian origin. The latter dominate by their richness and abundance. They belong to Trechidae and Scaritidae families (Caraboidea) specialized in this type of environment $[8,9]$.

Constant species are not numerous and are halophilic species adapted to extreme conditions of these hypersaline environments.

Another type of adaptation characterizes these environments. It appears as a precise succession of tiger Beetles, as described in Spain [13], and a separate proliferation in time for Pogonus and Pogonistes. This is a particular phenomenon specific to temporary riparian environments. Indeed, these biotopes are very limited in space and time, and they force their populations to accelerate their life cycles so that species with the exact ecological requirements can succeed without competing.

\section{References}

1. W.D. Dudley, The ecology of temporary waters, Ed. Croom Helm : 183 (1987)

2. L. Bigot, G. Gautier, Originalité et intérêt écologique de la communauté ripicole et pélophile de surface. Bull. Mus. Hist. Nat. Marseille, 41 :13-30, (1981)

3. M. Antoine, Coléoptères carabiques du Maroc: $1^{\text {ère }}$ partie Mém. Soc. Sc. Nat. Phys. Maroc, Zool., n. s., 1 : 1-177, (1955)

4. M. Antoine, Coléoptères carabiques du Maroc : $2^{\text {ème }}$ partie Mém. Soc. Sc. Nat. Phys. Maroc, Zool., n. s., 3 : 1-137, (1957)

5. M. Antoine, Coléoptères carabiques du Maroc: $3^{\text {ème }}$ partie Mém. Soc. Sc. Nat. Phys. Maroc, Zool., n. s., 6 : 1-150, (1959)

6. M. Antoine, Coléoptères carabiques du Maroc : $4^{\text {ème }}$ partie Mém. Soc. Sc. Nat. Phys. Maroc, Zool., n. s., 8 : 1-180, (1961)

7. M. Antoine, Coléoptères carabiques du Maroc : $5^{\text {ème }}$ partie Mém. Soc. Sc. Nat. Phys. Maroc, Zool., n. s., 9 : 1-153, (1962)

8. F. Rueda, C. Montes, Los Carabidos (Col. Carabidae) de las orillas de las lagunas salinas de la peninsula Iberica; Aspectos faunisticos. Actas III Congreso Iberico de Entomologia : 651-662 (1988)

9. J. Serrano, A.S. Ortiz, J. Gallian, Los Carabidae de lagunas y rios de la Submeseta Sur, España (Coleoptera, Adephaga). Bol. Asoc. Esp. Entom. Vol. 14 : 199-210 (1990) 
10. C. Favet, Contribution à l'étude écologique des populations ripicoles de Basse-Durance, Bull. Mus. Hist. Nat. Marseille, 44 : 47-61 (1984)

11. G. Gautier, Etude écologique des communautés de Tréchidés des bords d'étangs en Camargue LagunoMarine : I- Le milieu et la faune (composition, structure et dynamique). Bull. Ecol., t. 10, $3: 181-202$ (1979)
12. G. Chavanon, Contribution à la connaissance des carabiques ripicoles de la Basse-Moulouya et de l'oued Za: Inventaire et distribution spatiotemporelle, Thèse Doc. Etat, Univ. Mohamed Ier, Fac. Sci. Oujda : 159p. (1994a)

13. J. Vives, E. Vives, Coleópteros halóphilos de Los Monegros, Bol. Asoc. Esp. Entom. Vol 2 : 205-214 (1978) 